\title{
[3H]GBR-12935 Binding Sites in Human Striatal Membranes: Binding Characteristics and Changes in Parkinsonians and Schizophrenics
}

\author{
Midori HIRAI', Noboru KITAMURA ${ }^{1}$, Takeshi HASHIMOTO², \\ Takashi NAKAI2, Tatsuo MITA2 ${ }^{2}$, Osamu SHIRAKAWA2, Takashi YAMADORI ${ }^{3}$, \\ Takehiko AMANO ${ }^{4}$, Sadako A. NOGUCHI-KUNO ${ }^{5}$ and Chikako TANAKA ${ }^{1 *}$ \\ 'Department of Pharmacology. ${ }^{2}$ Department of Psychiatry and Neurology, and \\ ${ }^{3}$ Department of Anatomy. Kobe University School of Medicine. Kobe 650. Japan \\ ${ }^{4}$ Mitsubishi-Kasei Institute of Life Sciences, Machida. Tokyo 194. Japan \\ ${ }^{5}$ Utano National Hospital. Kyoto 616. Japan
}

Accepted March 18, 1988

\begin{abstract}
The binding of the diphenyl-substituted piperazine derivative. $\left[{ }^{3} \mathrm{H}\right] \mathrm{GBR}$ 12935, a selective dopamine uptake inhibitor, to the post-mortem human putamen was studied. Inhibition curves by dopamine uptake inhibitors suggested the existence of two populations of $\left[{ }^{3} \mathrm{H}\right] \mathrm{GBR}-12935$ binding sites: one is potently inhibited by mazindol and/or nomifensine, and the second binding site is benztropine- and/or GBR 12909 -sensitive. In the human putamen, [ ${ }^{3} \mathrm{H}$ ] GBR-12935 labeled both these two distinct binding sites. The $\left[{ }^{3} \mathrm{H}\right] \mathrm{GBR}-12935$ binding displaced by mazindol was enriched in the mouse and rat striatum, but not in the cultured mouse neuroblastoma cell N1E-115. The mazindol-sensitive $\left[{ }^{3} \mathrm{H}\right] \mathrm{GBR}$ 12935 binding site increased in the presence of sodium and markedly decreased in the putamen from parkinsonians (45\% of controls). On the other hand, the $\left[{ }^{3} \mathrm{H}\right]$ GBR-12935 binding displaced by benztropine showed no sodium-dependent increase and was not decreased in the putamen from parkinsonians. In the putamen from schizophrenics, the $\left[{ }^{3} \mathrm{H}\right] \mathrm{GBR}-12935$ binding did not significantly change in the density, while that displaced by mazindol tended to increase. It is concluded that in the human putamen. $\left[{ }^{3} \mathrm{H}\right] \mathrm{GBR}-12935$ binds to two distinct sites. One site is partially sodium-dependent and appears to be associated with a high-affinity dopamine uptake system on dopaminergic nerve terminals. The second binding site shows no sodium-dependency and may be associated with a nondopaminergic and/or extraneuronal DA uptake system.
\end{abstract}

The principle mechanism for termination of the actions of synaptically released monoamines such as dopamine (DA), norepine phrine (NE) and serotonin has been considered to be their uptake into the presynaptic terminal. Selective transport mechanisms exist for each amine (1), but the elucidation of the DA uptake mechanisms has been limited because of the absence of selective ligands for labeling the DA transport complex. Recent studies using radiolabeled DA uptake

\footnotetext{
* To whom correspondence should be addressed.
}

blockers have described specific and saturable binding sites associated with the neuronal DA uptake system in the striatal membranes (2-7). Most of all these ligands have a poor selectivity for the DA transport complex compared with the norepinephrine (NE) uptake system. A series of diphenylsubstituted piperazine derivatives (8), 1-[2(2 - (diphenylmethoxy)ethyl] - 4 - (3 - phenylpropyl)-piperazine (GBR 12935) and GBR 12783, were introduced as ligands for labeling the DA transport complex with high selectivity and have provided a new tool for 
the study of DA transport system $(9-11)$.

Post-mortem human brains can provide useful information concerning human neuropharmacology and pathology. Especially, the brains of patients with Parkinson's disease (PD) have been chosen as a 'natural' nigrostriatal lesion model for studying dopaminergic transmission. The present study characterized the GBR-12935 binding sites in the post-mortem human putamen, as compared with those in the mouse and rat striatum, and the cultured mouse neuroblastoma N1E115 cells which take up DA (12). We found that in the human putamen, two distinct GBR-12935 binding sites existed and showed different sodium-sensitivity. One is partially sodium-dependent and decreased in the putamen from parkinsonians, which is related to the neuronal DA uptake. The second binding site, which also exists in the cultured cell N1E-115, shows no sodiumdependency and no alteration in the putamen from parkinsonians. Furthermore, we studied the alteration of the binding levels in the putamen from schizophrenics in which abnormalities of the central dopaminergic transmission have been indicated.

\section{Materials and Methods}

Chemicals: $\left.\quad{ }^{3} \mathrm{H}\right] \mathrm{GBR}-12935 \quad(38.6 \mathrm{Ci} /$ mmol) was purchased from New England Nuclear (Boston, MA). Mazindol was supplied by Sandoz (Tokyo, Japan); nomifensine by Hoechst-Japan (Kawagoe, Japan). benztropine by Nihon Merck-Banyu (Tokyo. Japan) and GBR 12909 by Research Biochemicals Inc. (U.S.A.).

Tissue preparation: Brains were obtained at autopsy from 8 patients with idiopathic Parkinson's disease (PD) (6 men, 2 women. age $71.9 \pm 2.3$ years). 15 patients with schizophrenia (10 men, 5 women, age $65.2 \pm 3.8$ years) and 20 control subjects with no known psycho-neurological diseases (16 men, 4 women, age $60.6 \pm 3.6$ years). The time between death and autopsy was $4.8 \pm 0.5$ hr for patients with PD, $13.3 \pm 2.5 \mathrm{hr}$ for those with schizophrenia and $8.6 \pm 1.6 \mathrm{hr}$ for the controls. The diagnostic criteria for idiopathic $P D$ included the clinical record (stage $V$ according to Hoehn and Yahr (13)) and histopathological evidence of depletion of pigmented nigral cells and the presence of Lewy bodies. The diagnosis for schizophrenia was based on DSM-III categories. All brain dissection was performed as described (14). In some cases, for statistical analysis, groups have been matched for age and post-mortem delay.

Cell culture: Mouse neuroblastoma clone N1E-115 cells were grown in Dulbecco's modified eagle medium (GIBCO) supplemented with $10 \%$ newborn calf serum. The cells were incubated at $37^{\circ} \mathrm{C}$ in an atmosphere consisting of $10 \% \quad \mathrm{CO}_{2}$ and $90 \%$ humidified air. The medium was changed at 2 day intervals. Cells were grown to confluency prior to use.

Membrane preparation: The striatum from mouse and rat and the putamen from human brain were homogenized in 20 vol. of icecold buffer (50 mM Tris- $\mathrm{HCl}, \mathrm{pH} 7.4,120$ $\mathrm{mM} \mathrm{NaCl}$ ) with a Brinkmann Polytron (setting at 7 for $15 \mathrm{sec}$ ). The homogenates were then centrifuged (for $20 \mathrm{~min}$ at $38,000 \times \mathrm{g}$ ) three times with resuspension of the intermediate pellets in fresh buffer. Cultured cells were harvested mechanically with a rubber policeman, pelleted at $600 \times \mathrm{g}$ for $10 \mathrm{~min}$, in the above buffer, homogenated and centrifuged as described above. The final pellets were stored at $-80^{\circ} \mathrm{C}$ until assayed.

Binding assay of $\left[{ }^{3} \mathrm{H}\right] \mathrm{GBR}-12935$ : Each incubation mixture consisted of $2 \mathrm{ml}$ of buffer $(50 \mathrm{mM}$ Tris- $\mathrm{HCl}, \mathrm{pH} 7.4$, containing $120 \mathrm{mM} \mathrm{NaCl}$ and $0.01 \%$ bovine serum albumin) containing $0.1-0.3 \mathrm{mg}$ of membrane proteins, $0.5 \mathrm{nM}$ or $1 \mathrm{nM}$ concentrations of $\left[{ }^{3} \mathrm{H}\right] \mathrm{GBR}-12935$, and when indicated, various other drugs. The mixtures were incubated for $45 \mathrm{~min}$ at $25^{\circ} \mathrm{C}$, and the binding process was terminated by rapid filtration under vacuum through a Whatman GF/B filter. Each of the filters was presoaked in $0.3 \%$ polyethyleneimine for at least $60 \mathrm{~min}$ before use to reduce the nonspecific absorption of free radioligand to glass filters. Nonspecific binding was defined as the binding in the presence of 5 " $\mathrm{M}$ mazindol or 20 / $M$ benztropine. Radioactivity on the filters was counted in a liquid scintillation spectrometer at $45 \%$ efficiency. Protein assay was performed by the method of Lowry et al. (15). 
Student's t-test (two-tailed) was used for statistical analysis.

\section{Results}

Drug inhibition of $\left[{ }^{3} \mathrm{H}\right] \mathrm{GBR}-12935$ binding: Inhibition curves of [ $\left.{ }^{3} \mathrm{H}\right] \mathrm{GBR}-12935$ (1 $\mathrm{nM}$ ) binding by four potent DA uptake inhibitors are shown in Fig. 1. In the mouse and rat striatum, the rank order of potencies was: GBR 12909>mazindol>nomifensine> benztropine. In the human putamen, the binding patterns of mazindol and nomifensine were different from those in the mouse and rat striatum, i.e., only $40-50 \%$ of the total $\left[{ }^{3} \mathrm{H}\right] \mathrm{GBR}-12935$ binding was inhibited at maximal concentration $(0.1 \mathrm{mM})$ of mazindol and nomifensine, whereas these drugs inhibited the binding more effectively than
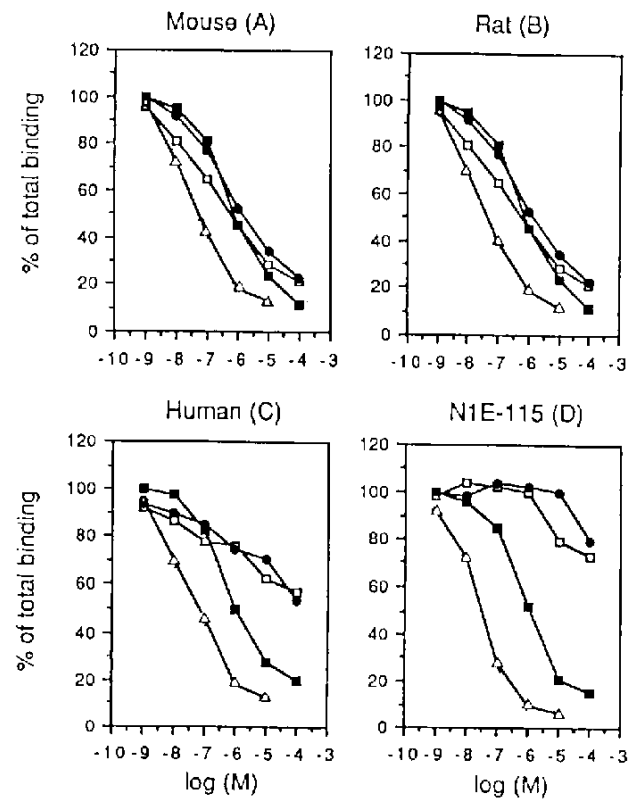

Fig. 1. Inhibition of $\left[{ }^{3} \mathrm{H}\right] \mathrm{GBR}-12935$ binding (1 $\mathrm{nM}$ ) to the mouse striatal (A), rat striatal (B), human putamen (C) and N1E-115 cell membranes (D) by mazindol $(\square)$, nomifensine (O). benztropine and GBR-12909 ( $\triangle$ ). Data are expressed as a percent of the total binding measured in the absence of each drug (mouse striatum, $3.1 \mathrm{pmol} / \mathrm{mg}$ protein: rat striatum, $3.5 \mathrm{pmol} / \mathrm{mg}$ protein; human putamen. $1.2 \mathrm{pmol} / \mathrm{mg}$ protein: N1E-115 cells, $2.1 \mathrm{pmol} / \mathrm{mg}$ protein), and represent the mean of at least five experiments performed in triplicate, in which similar results were obtained. benztropine at low concentration (1-10 nM). In contrast, GBR12909 and benztropine inhibited $\left[{ }^{3} \mathrm{H}\right] \mathrm{GBR}-12935$ binding with similar potencies in all tissues. The mazindoland/or nomifensine-insensitive site was displaced by GBR 12909 and benztropine, and was enriched in the human putamen. This binding site also existed in the cultured cell N1E-115 derived from mouse neuroblastoma which possesses a DA uptake system (12).

Sodium dependency of $\left[{ }^{3} \mathrm{H}\right] \mathrm{GBR}$ binding in human putamen: Previous reports have shown that in the rat, $\left[{ }^{3} \mathrm{H}\right] \mathrm{GBR}-12935$ binding associated with a DA uptake system is dependent upon sodium. whereas that in some brain regions and tissues was inhibited by sodium (11). The effect of sodium on $\left[{ }^{3} \mathrm{H}\right]$ GBR-12935 binding in the human putamen is shown in Fig. 2. When the $\left[{ }^{3} \mathrm{H}\right]$ GBR-12935 (1 nM) binding displaced by $5 \mu \mathrm{M}$ mazindol was measured as a function of $\mathrm{NaCl}$ concentration, sodium-dependent increase of the binding was observed; the mazindol-sensitive specific binding was increased by about $30 \%$ at the sodium concentration of $150 \mathrm{mM}$. This sodiumdependency of the binding in the human putamen was not so marked as that of rat striatum (11). In contrast, the specific bind-

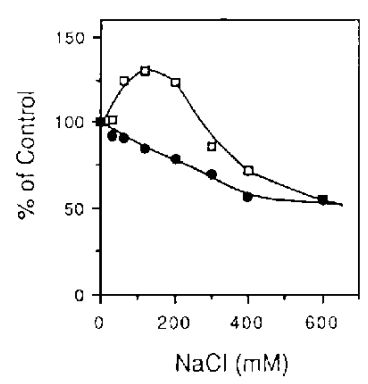

Fig. 2. Effect of $\mathrm{NaCl}$ on the specific binding of $\left[{ }^{3} \mathrm{H}\right] \mathrm{GBR}-12935$ (1 $\left.\mathrm{nM}\right)$ in the human putamen. Specific $\left[{ }^{3} \mathrm{H}\right] \mathrm{GBR}-12935$ binding was measured in the presence of increasing concentrations of $\mathrm{NaCl}$ at a ligand concentration of $1 \cap \mathrm{M}$. Nonspecific binding was determined with 20 " $\mathrm{M}$ benztropine (O) or $5 \mu \mathrm{M}$ mazindol ( $\square$ ). Data are expressed as a percent of the specific binding measured in the absence of $\mathrm{NaCl}$ (benztropine-displacable site. 920 $\mathrm{fmol} / \mathrm{mg}$ protein: mazindol-displacable site. 210 $\mathrm{fmol} / \mathrm{mg}$ protein) and represent the mean of at least three experiments performed in triplicate. in which similar results were obtained. 

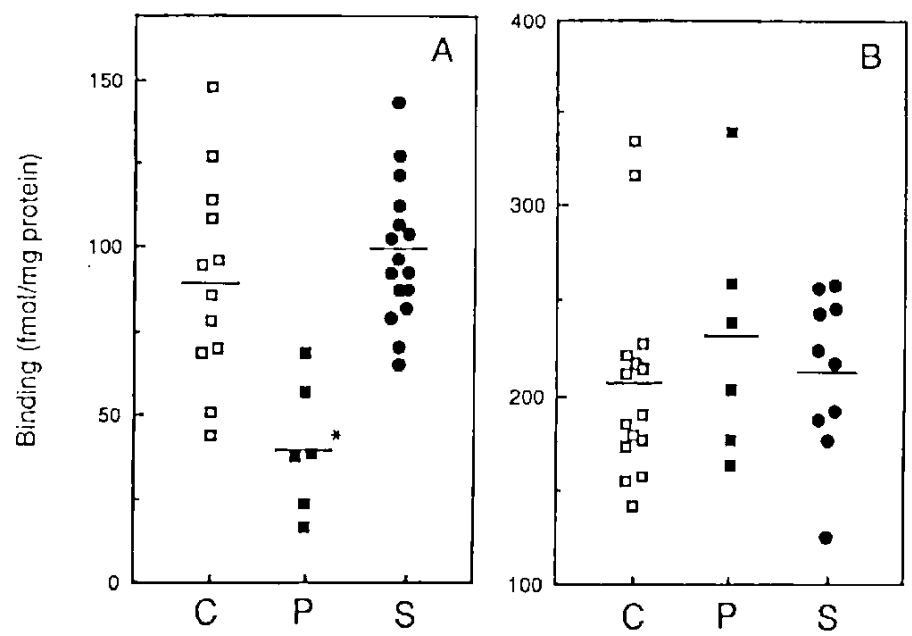

Fig. 3. Density of specific $\left[{ }^{3} \mathrm{H}\right] \mathrm{GBR}-12935$ binding sites in the putamen from controls (二), parkinsonians ( $\square$ ) and schizophrenics (O). Specific [ $\left.{ }^{3} \mathrm{H}\right] \mathrm{GBR}-12935$ binding was estimated at a ligand concentration of $0.5 \mathrm{nM}$. Nonspecific binding was determined with $5 \mu \mathrm{M}$ mazindol (A) or $20 \mu \mathrm{M}$ benztropine (B). Each point represents an individual subject. The horizontal bars represent the mean (fmol/ $\mathrm{mg}$ protein). Mean valuestS.E.M. (fmol/mg protein) are as follows: the 5 $\mu M$ mazindol-displacable site: controls, $90.4 \pm 8.9(n=15)$ : parkinsonians, $40.3 \pm 8.1 \quad(n=6)$, ${ }^{*} P<0.005$; schizophrenics, $98.7 \pm 5.5$ $(n-15)$; the $20 \mu \mathrm{M}$ benztropine-displacable site controls, $206.4 \pm 14.2 \quad(n=15)$; parkinsonians, $230.1 \pm 26.4(n=6)$ : schizophrenics. $212.3 \pm 13.6(n=10)$.

ing of $\left[{ }^{3} \mathrm{H}\right] \mathrm{GBR}-12935$ to the human putamen was inhibited by increasing concentrations of sodium when $20 / \mathrm{M}$ benztropine was used for determining the nonspecific binding. The specific $\left[{ }^{3} \mathrm{H}\right] \mathrm{GBR}-12935$ binding displaced by $20 / / \mathrm{M}$ benztropine also existed in N1E-115 cell membranes and was inhibited by increasing concentrations of sodium (data not shown).

The $\left[{ }^{3} \mathrm{H}\right]$ GBR-12935 binding in the putamen from patients with Parkinson's disease and schizophrenia: In the putamen from parkinsonians, the specific $\left[{ }^{3} \mathrm{H}\right] \mathrm{GBR}-12935$ (0.5 nM) binding displaced by $5 \mu \mathrm{M}$ mazindol was significantly lower (about $45 \%$ of control) than that in the putamen from controls $(P<0.005)$ (Fig. 3). The binding displaced by $5 \mu \mathrm{M}$ mazindol in the putamen from schizophrenics tended to increase, although the difference between the means was not statistically significant. When 20 " M benztropine was employed to determine nonspecific binding, no significant difference was seen between the controls, parkinsonians and schizophrenics. In schizophrenics, no significant changes of the binding levels was observed regardless of whether or not the patients had been on neuroleptics. The possible influences on the binding levels by age. the time from death to autopsy and the preservation time were neglected since no correlation was observed between the binding levels and these factors (data not shown). Furthermore, no significant changes in binding were found when the subjects were well matched for age. the time from death to autopsy and the preservation time.

\section{Discussion}

The $\left[{ }^{3} \mathrm{H}\right] \mathrm{GBR}-12935$ binding to the postmortem human putamen was shown to have some distinct properties from that to the mouse and rat striatum. Mazindol and nomifensine were potent inhibitors of the $\left[{ }^{3} \mathrm{H}\right] \mathrm{GBR}-12935$ binding in the striatal membranes of mouse and rat, in agreement with the previous report (11). In the human putamen the inhibition of $\left[{ }^{3} \mathrm{H}\right] \mathrm{GBR}-12935$ binding by mazindol and nomifensine was not as potent as in the mouse and rat striatum. The inhibition was $40-50 \%$ of the total binding at the maximal concentrations of 
these drugs. In contrast, GBR 12909 and benztropine inhibited $\left[{ }^{3} \mathrm{H}\right] \mathrm{GBR}-12935$ binding with similar potencies in all tissues. Furthermore, the Scatchard plots of the benztropine-sensitive binding in the human striatal membranes were curvilinear, indicating the multiple binding sites (data not shown). Thus, it seems that at least two populations of $\left[{ }^{3} \mathrm{H}\right] \mathrm{GBR}-12935$ binding sites exist in the human striatal membranes: one is mazindoland/or nomifensine-sensitive, and the second is benztropine-and/or GBR 12909 -sensitive. Recently. Andersen reported that in the rat striatal membranes, [ $\left.{ }^{3} \mathrm{H}\right]$ GBR-12935 labeled the classical DA uptake site and a piperazine acceptor site, although Scatchard analysis indicated a single binding site (16). When 5 $\mu \mathrm{M}$ mazindol was used to estimate nonspecific binding, Janowsky et al. (17) obtained a $K_{a}$ of $2.34 n M$ and a $B_{\max }$ of 1.36 $\mathrm{pmol} / \mathrm{mg}$ protein in the human caudate nucleus, while they reported a $K_{\mathrm{a}}$ of $\sim 1 \mathrm{nM}$ and $a B_{\text {max }}$ of $\sim 5 \mathrm{pmol} / \mathrm{mg}$ protein in the rat striatal membranes (11). Bonnet et al. (10). using $\left[{ }^{3} \mathrm{H}\right] \mathrm{GBR} 12783$, obtained a $\mathrm{K}_{d}$ of 1.6 $\mathrm{nM}$ and a $\mathrm{B}_{\max }$ of $10.3 \mathrm{pmol} / \mathrm{mg}$ protein in the rat striatal membranes. Thus, the $B_{\max }$ value of the mazindol-sensitive [ $\left.{ }^{3} \mathrm{H}\right] \mathrm{GBR}-$ 12935 binding site appeared to the lower in the human striatum than in the rat striatum, with a $K_{d}$ value similar to that of the rat striatum.

We found that the two distinct $\left[{ }^{3} \mathrm{H}\right] \mathrm{GBR}$ 12935 binding sites in the human putamen showed different sodium-sensitivity. It is generally accepted that the high-affinity DA uptake is sodium-dependent (1). Since the mazindol-sensitive [3H]GBR-12935 binding site showed a sodium-dependent increase, this site appears to be related to the highaffinity DA transport system. The reduction of the mazindol-sensitive [ $\left.{ }^{3} \mathrm{H}\right] \mathrm{GBR}-12935$ binding in the PD putamen and in the rat striatum lesioned with 6-hydroxydopamine supports this hypothesis $(11,17)$.

The degree of decreased bindings in the PD putamen agrees well with the recent report by Janowsky et al. (17). We obtained. however, rather lower binding levels as compared with those reported by Janowsky et al. (17), probably owing to the difference in membrane preparations. There is a noteworthy concept that it is necessary to lose $80-85 \%$ of the nigral neurons and to deplete the striatum of at least $80 \%$ of its dopamine content for frank symptoms of PD to appear (18). It. therefore, appears that the degree of observed reductions in mazindol-sensitive $\left[{ }^{3} \mathrm{H}\right] \mathrm{GBR}$ 12935 bindings is lower than that of neuronal loss. This discrepancy between the degrees of neuronal loss and the reduction of the mazindol-sensitive $\left[{ }^{3} \mathrm{H}\right] \mathrm{GBR}-12935$ binding may be attributable to the compensation mechanism. Alternatively, the $\left[{ }^{3} \mathrm{H}\right] \mathrm{GBR}$ 12935 appears to label sites unrelated to the neuronal high-affinity DA uptake system, as discussed below.

The $\left[{ }^{3} \mathrm{H}\right] \mathrm{GBR}-12935$ binding to the human putamen using benztropine as a displacer showed no sodium-dependent increase. This sodium-independency of $\left[{ }^{3} \mathrm{H}\right] \mathrm{GBR}-12935$ binding to the human putamen appears not to be artifacts due to the post-mortem delay and tissue handling, since the sodium dependency of $\left[{ }^{3} \mathrm{H}\right] \mathrm{GBR}-12935$ binding to the rat striatum was not altered after storage for at least up to $10 \mathrm{hr}$ at $25^{\circ} \mathrm{C}(\mathrm{O}$. Shirakawa et al., unpublished data). Such a sodiumindependent and benztropine-sensitive $\left[{ }^{3} \mathrm{H}\right]$ GBR-12935 binding site also exists in the cultured cells N1E-115. N1E-115 cells have a DA uptake system, yet its affinity for DA is very low $\left(K_{m}=\sim 10 \mu M\right)$, with temperature dependency and partial sodium dependency (O. Shirakawa et al., unpublished data). In addition. mazindol and nomifensine had little effect on the $\left[{ }^{3} \mathrm{H}\right] \mathrm{GBR}-12935$ binding in N1E-115. Since the benztropine-sensitive [3H]GBR-12935 binding site did not decrease in the PD putamen in which the dopaminergic nigrostriatal pathway is degenerated, this binding site may be related to extraneuronal components such as the DA uptake site in glial cells. It was reported that monoamines such as DA was taken up by not only neurons but also astrocytes (19). Thus, the heterogeneity of $\left[{ }^{3} \mathrm{H}\right] \mathrm{GBR}-12935$ binding sites in the human putamen may reflect different compartments of the DA uptake system in the brain. We cannot, however, exclude the possibility that the differences in the binding reflects the species differences in the characteristics of the DA transporter system per se.

In the present study, we could not find 
apparent abnormalities of [3H]GBR-12935 binding in the putamen from schizophrenics. Although it has been widely accepted that there are abnormalities of the dopaminergic transmission in schizophrenia, our results suggest that disturbances in the DA uptake system, if any, are not primarily associated with schizophrenic etiology and symptomatology.

In conclusion, characteristics of $\left[{ }^{3} \mathrm{H}\right] \mathrm{GBR}$ 12935 binding sites showed species differences, and there are two distinct $\left[{ }^{3} \mathrm{H}\right] \mathrm{GBR}$ 12935 binding sites in the human putamen: one is partially sodium-dependent and potently displaced by mazindol and nomifensine, and the second binding site is inhibited by sodium and benztropine- and/or is GBR 12909-sensitive. The former is associated with the high-affinity DA uptake system on the dopaminergic nerve terminals. and the latter may be related mainly to nondopaminergic and/or extraneuronal components.

Acknowledgments: This study was supported by grants from the Ministry of Education. Science and Culture and the Ministry of Health and Welfare. Japan.

\section{References}

1 Iversen, L.L: Uptake mechanisms for neurotransmitter amines. Biochem. Pharmacol. 23, 1927-1935 (1974)

2 Javitch, J.A., Blaustein, R.O. and Snyder, S.H. $\left[{ }^{3} \mathrm{H}\right]$ Mazindol binding associated with neuronal dopamine and norepinephrine uptake sites. Mol. Pharmacol. 26, 35-44 (1984)

3 Scatton, B., Dubois, A., Dubocovich, M.L., Zahnister, N.R. and Fage, D.: Quantitative autoradiography of ${ }^{3} \mathrm{H}$-nomifensine binding sites in rat brain. Life Sci. 36. 815-822 (1985)

4 Kennedy, L.T. and Hanbauer, I.: Sodiumsensitive cocaine binding to rat striatal membrane: possible relationship to dopamine uptake sites. J. Neurochem. 41, 172-178 (1983)

5 Dubocovich, M.L, and Zahnister, N.R.: Binding characteristics of the dopamine uptake inhibitor $\left[{ }^{3} \mathrm{H}\right]$ nomifensine to striatal membranes. Biochem. Pharmacol. 34, 1137-1144 (1985)

6 Janowsky, A., Schweri, M.M., Berger, P., Long. R., Skolnick, P. and Paul, S.M.: The surgical and chemical lesions on striatal $\left[{ }^{3} \mathrm{H}\right]$ threo- $( \pm)$ methylphenidate binding: correlation with $\left[{ }^{3} \mathrm{H}\right]$ dopamine uptake. Eur. J. Pharmacol. 108, 187. 191 (1985)
7 Schoemarker, H., Pimoule, C., Arbilla, S., Scatton, B., Avoy-Agid, F.J and Langer, S.Z.: Sodium dependent $\left[{ }^{3} \mathrm{H}\right]$ cocaine binding associated with dopamine uptake sites in the rat striatum and human putamen decrease after dopaminergic denervation and Parkinsons disease. Naunyn Schmiedeberg's Arch. Pharmacol. 329, 227-235 (1985)

8 van der Zee, P., Koger, H.S., Gootjes, J. and Hespe, W.: 1,4-Diaik(en)yl-piperazines as selective and very potent inhibitors of dopamine uptake. Eur. J. Med. Chem. 15, 363-370 (1980)

9 Heikkila, R.E. and Manzino, L.: Behavioral properties of GBR 12909, GBR 13069 and GBR 13098: specific inhibitors of dopamine uptake. Eur. J. Pharmacol. 103, 241-248 (1984)

10 Bonnet, J.J., Protais, P., Chagroui, A. and Costentin, J.: High-affinity $\left[{ }^{3} \mathrm{H}\right] \mathrm{GBR} 12783$ binding to a specific site associated with the neuronal dopamine uptake complex in the central nervous system. Eur. J. Pharmacol. 126, 211-222 (1986)

11 Janowsky, A., Berger, P., Vocci, F., Labarca, R., Skolnick, P. and Paul, S.M.: Characterization of sodium-dependent $\left[{ }^{3} \mathrm{H}\right] \mathrm{GBR}-12935$ binding In brain: a radioligand for selective labelling of the dopamine transport complex. J. Neurochem. 46, 1272-1276 (1986)

12 Breakfield, X.O.: Reserpine sensitivity of catecholamine metabolism in murine neuroblatoma clone N1E-115. J. Neurochem. 25, 877-882 (1975)

13 Hoehn, M.M. and Yahr, M.D.: Parkinsonism: onset, progression and mortality. Neurology 17, 427-442 (1967)

14 Nishino, N., Noguchi-Kuno, S.A., Sugiyama, T. and Tanaka, $C_{.}:\left[{ }^{3} \mathrm{H}\right]$ Nitrendipine binding sites are decreased in the substantia nigra and striatum of the brain from patients with Parkinson's disease. Brain Res. 377, 186-189 (1986)

15 Lowry, O.H., Rosenbrough, M.J., Farr, A.L. and Randall, R.J.: Protein measurement with the Folin phenol reagent. J. Biol. Chem. 193, 421428 (1951)

16 Andersen, P.H.: Blochemical and pharmacological characterization of $\left[{ }^{3} \mathrm{H}\right] \mathrm{GBR} 12935$ binding in vitro to rat striatal membranes: labeling of the dopamine uptake complex. I. Neurochem. 48, 1887-1896 (1987)

17 Janowsky, A., Vocci, F., Berger, P., Angel, I., Zelnik, N., Kleinman, J.E., Long, R., Skolnick, P. and Paul, S.M.: $\left[{ }^{3} \mathrm{H}\right] \mathrm{GBR}-12935$ binding to the dopamine transporter is decreased in the caudate nucleus in Parkinson's disease. J. 
Neuiochem. 49, 617-621 (1987)

18 Marsden, C.D.: Basal ganglia disease. Lancet 2, 21-27 (1982)

19 Kimelberg, H.K.: Occurrence and functional significance of serotonin and catecholamine uptake by astrocytes. Biochem. Pharmacol. 35, 2273-2281 (1986) 